\title{
Quality Attributes of Tapioca Meal Fortified With Defatted Soy Flour
}

\author{
${ }^{1}$ Balogun M.A.*, ${ }^{1}$ Karim O.R., ${ }^{1}$ Kolawole, F.L. and ${ }^{2}$ Solarin A.O. \\ ${ }^{1}$ Department of Home Economics and Food Science, University of Ilorin \\ ${ }^{2}$ Department of Food Technology, Federal Polytechnic, Offa. \\ * Corresponding author, Department of Home Economics \& Food Science, University \\ of Ilorin, Ilorin, Nigeria \\ balogun.ma@unilorin.edu.ng (+2348055948515)
}

\begin{abstract}
Tapioca is a dried starchy powdery extract made from cassava which is popular in the eastern part of Nigeria. It has little or no protein thus it needs to be fortified with protein rich crops like soy beans. Enriched tapioca meal was produced from cassava starch and defatted soy flour. The cassava starch and defatted soy flour were mixed in the ratio 100:0, 95:5, 90:10, 85:15, and 80:20 to produce tapioca meal. Proximate and sensory analyses were evaluated for the tapioca meals. The proximate composition of tapioca meals ranged in values of 15.08 to $15.20 \% ; 1.20$ to $10.73 \%, 2.50$ to $2.82 \%, 68.29$ to $79.30 \%, 2.2$ to $2.40 \%$ and 0.60 to $0.66 \%$ for moisture, crude protein, ash, carbohydrate, crude fiber and fat, respectively. There were significant differences $(p<0.05)$ in values obtained for protein, ash and carbohydrate contents. The sample with 80:20 cassava starch and defatted soy flour had the highest protein content and the least moisture content. It was also rated highest in terms of overall acceptability from the sensory evaluation. Consequently fortification of tapioca with defatted soy flour increased the nutritional quality of tapioca meal and thus a complete meal was obtained from this fortification. Such meal can be recommended for people that are overweight because of its relatively low fat content.
\end{abstract}

\section{INTRODUCTION}

Cassava (Manihot esculenta crantz) which belongs to the family Euphorbiaceae is of two major varieties which are Manihot esculenta and Manihot utilizima (Osuji and Anih, 2011). It is one of the most important food crops grown in the tropics. It is a major root crop in the tropics and its starchy roots are significant source of calories for more than 500 million people world-wide (FAO, 2005). The production of cassava for human consumption has been estimated to be $65 \%$ of cassava products while $25 \%$ is for industrial use, mostly as starch(6\%) or animal feed (19\%) and 10\% lost as waste (Fish and Trim, 1993). Among the starchy staples, cassava gives a carbohydrate production of about $40 \%$ higher than rice and $25 \%$ more than maize, with the result that cassava is the cheapest source of calories for both human nutrition and animal feedings. A typical composition of the cassava root is moisture (70\%), starch (24\%), fibre (2\%), protein 
(1\%) and other substances including minerals (3\%) (Burell, 2003).

Cassava is processed into a variety of products such as 'gari', 'fufu', 'elubo', 'abacha' and tapioca in Nigeria and some parts of the tropics. Cassava is processed into tapioca flour for several reasons including shelf-life extension, palatability improvement, as thickening agent in soups etc. It is available in several forms including granules, flakes, pellets and plain flour. Tapioca pearls are small white spheres, each about $2 \mathrm{~mm}$ in diameter. Tapioca is essentially a flavourless starchy ingredient produced from treated and dried cassava root (FAO, 2005). Tapioca starch is very fine and is often used as a substitute for corn starch. Soybean (Glycine max merrill) belongs to the family Leguminosae. It is an important oil seed and is usually grown as a food crop. Soybean protein provides a source of low- cost protein with good nutritional value (Iwe, 2003). Soybean is widely used in developing countries as a protein-rich food mixture to foods deficient in limiting amino acids such as methionine and lysine (Iwe, 2003). Soybean can be processed to a variety of products such as soy flour, soy milk, soy yoghurt, soy cake, soy meal, etc.

One major problem with tapioca as a food commodity is that it is a starchy food with little or no protein. Tapioca meal without any additive is bland. Thus, there is the need to fortify it with crops that have high protein content like soybean. Therefore, incorporation of soybeans into tapioca will help increase its nutritional content and promote its acceptability among consumers. The objectives of this study are to produce enriched tapioca meal from cassava starch and defatted soy flour, assess the nutritional composition and acceptability of the fortified tapioca.

\section{Materials}

\section{MATERIALS AND METHODS}

The materials used (cassava and soy bean) were bought from a local market in Kwara State.

\section{Preparation of cassava starch}

Cassava starch was produced using traditional method as described by Asiedu (1989). The freshly harvested cassava tubers were hand peeled washed and then grated into pulp. The starch was washed out through a filter cloth and was allowed to settle before decanting the residual water. The resulting starch was then oven dried at $40^{\circ} \mathrm{C}$ for 3 hours (Fig 1). 


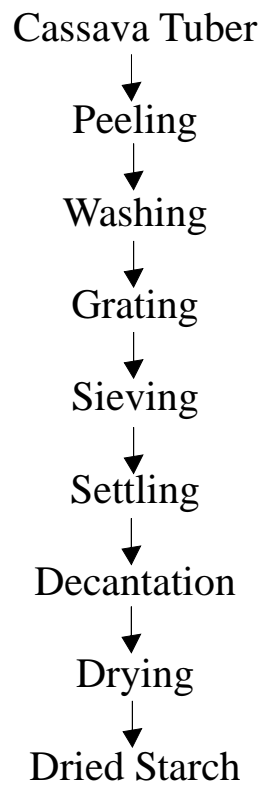

Fig 1: Flow Chart for Cassava Starch Production

\section{Preparation of Defatted Soy Flour}

The method described by Iwe, (2003) was used with some modifications to prepare defatted soy flour. Soy bean seeds were sorted, blanched for 30 minutes and soaked for about 12 hours. The grains were dehulled, dried in hot air oven at $40^{\circ} \mathrm{C}$ for 4 hours. The dried beans were milled using the attrition mill (dry milling). Water was added to the mill to form a mixture in the ratio of 4:1 of water to flour. The resultant mixture was stirred vigorously for 20 minutes and the oil was skimmed off. The process was repeated until the milk stopped foaming. The defatted soy slurry was drained using clean muslin cloth, oven dried at $40^{\circ} \mathrm{C}$ for 4 hours and dry milled into flour. The flour was sieved to obtain fine particles (Fig 2). 


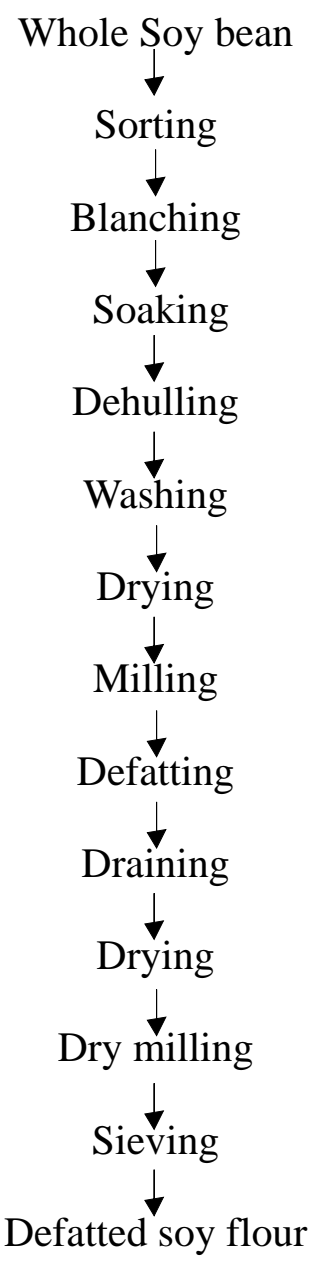

Fig 2: Flow Chart for the Production of Defatted Soy Flour

\section{Formulation of Enriched Tapioca Meal}

Cassava starch and defatted soy flour meal were mixed at ratio 100:0, 95:5, 90:10, 85:15 and 80:20 respectively, to produce the tapioca-soy flour mixture. The mixture was moistened with water in the ratio 2:1 of water to flour, roasted in a shallow pot at a low temperature in order to aid gelatinization of the starch and dried at $40^{\circ} \mathrm{C}$ for 4 hours. It was then packaged for analysis (Fig. 3). 


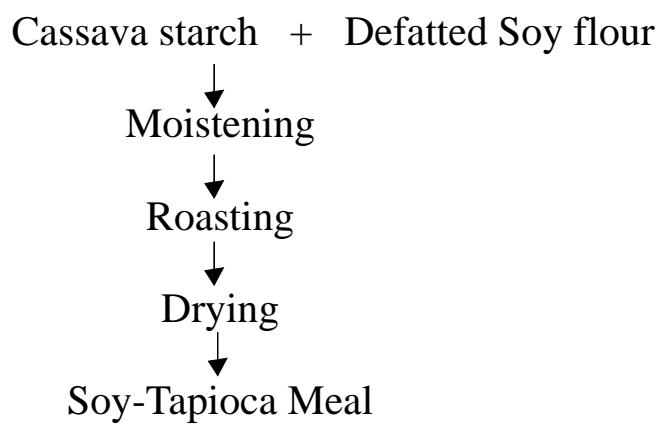

Fig 3: Flow Chart for the Production of Soy-Tapioca Meal

\section{Chemical Properties}

The proximate composition was determined according to the method AOAC (2000) while the carbohydrate (nitrogen free extract) was determined by difference.

\section{Sensory Analysis}

A 10-man panel conversant with tapioca was used for the organoleptic evaluation of colour, aroma, taste, texture and overall acceptability based on a nine-point hedonic scale (Iwe, 2007). The rating of samples ranged from 1 (dislike extremely), 2 (dislike very much), 3 (dislike moderately), 4 (dislike slightly), 5 (neither like nor dislike), 6 (like slightly), 7 (like moderately), 8 (like very much) and 9 (like extremely).

\section{Experimental Design and Statistical Analysis}

The experimental design used was completely randomized design (CRD). Data obtained were subjected to one way analysis of variance (ANOVA) while means were separated by Duncan's multiple range test.

\section{RESULTS AND DISCUSSION}

The result of the proximate composition of soy-tapioca meal is presented in Table 1.

Table 1: Proximate Composition of Soy-Tapioca Meal

\begin{tabular}{lcccccc}
\hline Sample & $\begin{array}{c}\text { Moisture } \\
(\%)\end{array}$ & $\begin{array}{c}\text { Protein } \\
(\%)\end{array}$ & $\begin{array}{c}\text { Ash } \\
(\%)\end{array}$ & $\begin{array}{c}\text { CHO } \\
(\%)\end{array}$ & $\begin{array}{c}\text { Crude Fibre } \\
(\%)\end{array}$ & $\begin{array}{c}\text { Fat } \\
(\%)\end{array}$ \\
\hline $100: 0$ & $15.20^{\mathrm{a}}$ & $1.20^{\mathrm{a}}$ & $2.50^{\mathrm{a}}$ & $78.30^{\mathrm{a}}$ & $2.20^{\mathrm{a}}$ & $0.60^{\mathrm{a}}$ \\
$95: 5$ & $15.10^{\mathrm{a}}$ & $4.88^{\mathrm{b}}$ & $2.61^{\mathrm{ab}}$ & $74.43^{\mathrm{b}}$ & $2.34^{\mathrm{a}}$ & $0.64^{\mathrm{a}}$ \\
$90: 10$ & $15.08^{\mathrm{a}}$ & $6.25^{\mathrm{c}}$ & $2.70^{\mathrm{b}}$ & $72.96^{\mathrm{c}}$ & $2.37^{\mathrm{a}}$ & $0.64^{\mathrm{a}}$ \\
$85: 15$ & $15.10^{\mathrm{a}}$ & $9.63^{\mathrm{d}}$ & $2.78^{\mathrm{b}}$ & $69.45^{\mathrm{d}}$ & $2.39^{\mathrm{a}}$ & $0.65^{\mathrm{a}}$ \\
$80: 20$ & $15.10^{\mathrm{a}}$ & $10.73^{\mathrm{e}}$ & $2.82^{\mathrm{b}}$ & $68.29^{\mathrm{d}}$ & $2.40^{\mathrm{a}}$ & $0.66^{\mathrm{a}}$ \\
\hline
\end{tabular}


Values are means of triplicate determinations on fresh weight basis; means within rows having different superscripts differ significantly $(\mathrm{p}<0.05)$.

The result showed that the moisture content of the samples ranged between 15.08 and $15.20 \%$. The values of the moisture content were, however, not significantly different from each other even as the level of addition of defatted soy flour increased. The moisture reported here was in agreement with the work of Oyewole and Obieze, (1995). The protein content of the tapioca meal ranged between $1.20 \%$ and $10.73 \%$ in samples from $100 \%$ cassava starch and $20 \%$ defatted soy flour addition respectively. There was a significant increase $(p<0.05)$ in the protein content with increase in the addition of defatted soy flour. This observation agrees with previous findings of Iwe (2003). The fat content of the soy-tapioca meal ranged from $0.6 \%$ in samples from $100 \%$ cassava starch to $0.66 \%$ in the $20 \%$ defatted soy flour addition. It was observed that the fat content increased slightly as the addition of defatted soy flour increased. However there was no significant difference among the values obtained. This was in consistent with the work of Obadina et al., (2010). The ash content of the samples ranged from $2.50 \%$ to $2.82 \%$ in $100 \%$ cassava starch and $20 \%$ defatted soy flour addition respectively. This followed similar trend observed in protein and fat content. This result suggests that the added soy flour increased the proportion of ash present. This is a welcome development, as the consumer will have the opportunity of balancing their diet due to the increasing addition of minerals from ash. The carbohydrate content ranged between $68.29 \%$ at $20 \%$ addition of defatted soy flour and $78.39 \%$ at $0 \%$ addition. The values obtained showed a significant decreasing trend with corresponding increase in protein, fat and ash content. The decrease may be attributed to the low level of carbohydrate in the defatted soy flour. This observation agrees with the findings of Obadina et al., (2010). The crude fibre of the samples ranged from $2.20 \%$ to $2.40 \%$ at $0 \%$ and $20 \%$ addition of defatted soy flour respectively. Although there was a slight increase in the crude fibre, there was no significant difference in the samples upon increase in the addition of defatted soy flour. This agrees with the work of Obadina et al., (2010).

The result of the sensory analysis is shown in Table 2 and it is based on the perception of panelists to the different attributes.

Table 2: Sensory Quality Scores of Soy-Tapioca Meal

\begin{tabular}{|l|l|l|l|l|l|}
\hline Sample & Colour & Aroma & Taste & Texture & $\begin{array}{l}\text { Overall } \\
\text { acceptability }\end{array}$ \\
\hline $100: 0$ & $5.98^{\mathrm{a}}$ & $5.83^{\mathrm{a}}$ & $7.19^{\mathrm{b}}$ & $6.24^{\mathrm{a}}$ & $6.62^{\mathrm{a}}$ \\
\hline $95: 5$ & $6.38^{\mathrm{b}}$ & $6.13^{\mathrm{b}}$ & $7.22^{\mathrm{b}}$ & $6.20^{\mathrm{a}}$ & $6.70^{\mathrm{b}}$ \\
\hline $90: 10$ & $6.75^{\mathrm{c}}$ & $7.00^{\mathrm{d}}$ & $7.12^{\mathrm{a}}$ & $6.21^{\mathrm{a}}$ & $6.93^{\mathrm{c}}$ \\
\hline $85: 15$ & $6.75^{\mathrm{c}}$ & $6.82^{\mathrm{c}}$ & $7.25^{\mathrm{c}}$ & $6.20^{\mathrm{a}}$ & $6.93^{\mathrm{c}}$ \\
\hline $80: 20$ & $6.85^{\mathrm{d}}$ & $7.25^{\mathrm{c}}$ & $7.20^{\mathrm{b}}$ & $6.19^{\mathrm{a}}$ & $7.24^{\mathrm{d}}$ \\
\hline
\end{tabular}


Means within rows having different superscripts differ significantly $(\mathrm{p}<0.05)$.

As shown in Table 2, all the samples were found to be acceptable by the panelists because their scores were above average. The sample with $80 \%$ cassava starch and $20 \%$ defatted soy flour was rated highest in terms of colour (6.85), aroma (7.25) and overall acceptability (7.24); sample with $85 \%$ cassava starch and $15 \%$ defatted soy flour most preferred in terms of taste while the sample with $100 \%$ cassava starch was rated highest in terms of texture (6.24). This was not consistent with the findings of Obadina et al., (2010).

\section{CONCLUSION}

Fortification of tapioca meal with soy flour caused a significant increase in the protein content of the samples. The sample with $20 \%$ soy flour had the highest protein and was also rated highest in terms of overall acceptability by the panelists. Hence the addition of soy flour to cassava starch is recommended up to $20 \%$ level.

\section{REFERENCES}

Association of Official Analytical Chemists (AOAC, 2000). Official Methods of Analysis (1 $7^{\text {th }}$ Edition). Washington D.C.

Asiedu, J.J. (1989). Processing Tropical Crops: A technological Approach. (1 $1^{\text {st }}$ ed.) 3-8. London: Macmillan Publishers.

Burell, M. M. (2003). 'Starch: The Need for Improved Quality or Quantity: An Overview'. Journal of Experimental Botany. 54 (382): 451- 456.

Food and Agricultural Organization (FAO, 2005). Food Outlook. 36

Fish, D.M. and Trim, D.S. (1993). 'A Review of Research in the Drying of Cassava'. Tropical Science. 33(2): 191-203.

Iwe, M.O. (2003). The Science and Technology of Soy Bean. pp 40-45. Enugu: Rojoint Communication Services Limited.

Iwe, M.O. (2007). Currrent Trend in Sensory Evaluation of Foods. pp 118-137. Enugu: Rojoint Communication Services Limited.

Obadina, A.O., Oyewole, O.B. and Olaleye, A.O. (2010). 'Development and Evaluation of Fortified Tapioca Meal with Coconut and Banana Pulp'. Nigerian Food Journal. 28 (2): 294-301

Osuji, C.M. and Anih, P.O. (2011). 'Physical and Chemical Properties of Glucose Syrup from Different Cassava Varieties'. Nigerian Food Journal. 29 (1): 83 - 89.

Oyewole, O.B. and Obieze, N. (1995). 'Processing and Characteristics of Tapioca-Meal from Cassava'. Tropical Science. 35: 401-404. 